\title{
Study of Agronomic and Environmental Profile of Compost and Fine Fraction Produced and Stored in a Shed at Composting Site: ENPRO Composting Site, Lomé, Togo
}

\author{
Etsè Aziablé*, Edem Komi Kolédzi \\ Department of Chemistry, University of Lomé, Lomé, Togo \\ Email address: \\ meaaziable@yahoo.fr (E. Aziablé), meaaziable@gmail.com (E. Aziablé) \\ ${ }^{*}$ Corresponding author
}

To cite this article:

Etsè Aziablé, Edem Komi Kolédzi. Study of Agronomic and Environmental Profile of Compost and Fine Fraction Produced and Stored in a Shed at Composting Site: ENPRO Composting Site, Lomé, Togo. Science Journal of Chemistry. Vol. 6, No. 5, 2018, pp. 95-98.

doi: $10.11648 / j . s j c .20180605 .13$

Received: October 5, 2018; Accepted: November 8, 2018; Published: December 5, 2018

\begin{abstract}
Composting is one of the safest ways to recycle household solid waste. This study aims at evaluating the quality of the agronomic profile of the compost and fine fraction collected on the composting platform of the NGO ENPRO in July 2014. The quality of the finished product was sought by the analysis of the agronomic and environmental profile. The results of the analyzes of the agronomic and environmental profile of compost and the fine fraction produced and stored for several months in a shed at the ENPRO composting site in Lomé, Togo show that the long lasting storage of compost on the platform (stored at least 3 months under the shed) induces a significant change in the agronomic profile: significant loss of nitrogen and significant mineralization of organic matter. The analysis of the environmental profile of the 2 compost samples and the fine fraction yielded contents of low levels of trace metal elements, very below the limit values of the French standard U44051. As a result, the compost obtained is a stable product, hygienic, rich in nutrients and organic matter. This organic matter content will allow the retention of trace metal elements. The higher this concentration, the more metals will be trapped thus decreasing their bioavailability. The risk would therefore be low in terms of phytotoxicity after soil amendment. This compost can stabilize or immobilize the solid phase metals. This compost will pave the way for agronomic promotion.
\end{abstract}

Keywords: Agronomic Profile, Environmental Profile, Compost

\section{Introduction}

Demographic growth and ever-increasing urbanization in developing countries are responsible for a large production of household solid waste. This large production of waste has become a worrying problem that local leaders are facing. Consequently, residents are increasingly aware of its risks. These wastes, which are rich in organic matter and mineral elements and provide an opportunity for farmers to fertilize or improve the quality of agricultural soils, can be recycled through composting.

The direct use of these wastes can present many risks and constraints related to their handling and use, due to the possible presence of pathogens [1]. This waste should therefore be chemically and / or biologically packaged before being used. Experiments carried out in the USA and in Europe [1], show that composting is a simple biological technique, which allows a promotion of these wastes if only the future of the trace elements is ensured.

Composting is a biological process of degradation and humification of organic matter. The highly stable final product does not contain phyto-toxicity and pathogenic microbes $[1,2]$. It is an excellent soil enriching agent. Very rich in humic substances, it improves the physical and chemical properties and stimulates the biological activity of the soil [1, 3]. It also contains nutrients for plants [1, 4]. Before enriching or fertilizing the soil with compost, it must reach maturity. The parameters used to evaluate the maturity and stability of compost are most often the chemical, physical, biological and spectroscopic parameters [1, 5]. This study aims at evaluating the quality of the agronomic profile of the compost and fine fraction collected on the composting platform of the NGO ENPRO in July 2014.

\section{Materials and Methods}

\subsection{Composting Procedure}

The raw materials consist mainly of fermentable waste 
from various places namely:

(1) fermentable wastes from garbage in the city of Lomé. These fermentable wastes are obtained following a manual sorting on table / sieve of the fraction to be composted.

(2) fermentable wastes from household waste in the market of Gbonssime in Lomé. They are obtained through a selective collection of garbage from the resellers of the Gbonssimé market of Lomé in Togo. The waste in this market is essentially a mixture of garbage, manure and cowpat. By hypothesis, it is a source of nutrients for the compost and thus for the grounds. With this regard, the composting platform sells more expensive compost of waste from this market.

For each type of waste, $1211 \mathrm{~kg}$ of fermentable waste is collected. For composting, the heap method was used to produce the composts: Lomé compost 1 (fermentable waste garbage) and Lomé compost 2 (fermentable waste from rubbish from the market of Gbonssimé).

To obtain representative samples, a quartering is done for each composting, and compost samples were collected at several locations. The samples taken are mixed for good homogenization. After drying, the samples are crushed and sieved with a $2 \mathrm{~mm}$ sieve in order to obtain a homogeneous powder.

\subsection{Analytical Method}

\subsubsection{Analysis of Agronomic Parameters}

The agronomic parameters that have been determined are: dry matter $(\mathrm{DM})$, organic matter $(\mathrm{OM})$, nitrogen $(\mathrm{N})$, phosphorus in the form of $\mathrm{P}_{2} \mathrm{O}_{5}$, potash in the form of $\mathrm{K}_{2} \mathrm{O}$ and calcium in the form of $\mathrm{CaO}$. The dry matter and the organic matter were determined according to standard NF EN 13040; nitrogen according to standard NF EN 13654-2 and phosphorus in the form of $\mathrm{P}_{2} \mathrm{O}_{5}$, potash in the form of $\mathrm{K}_{2} \mathrm{O}$ and calcium in the form of $\mathrm{CaO}$ were determined by the $\mathrm{X} 31-$ 150 method / method according to NF EN 13650-NF EN ISO 11885 .

\subsubsection{Environmental Analyzes}

The environmental analysis consists in determining the concentrations of metallic trace elements. The metal trace elements analyzed are: cadmium $(\mathrm{Cd})$, copper $(\mathrm{Cu})$, nickel $(\mathrm{Ni})$, lead $(\mathrm{Pb})$, chromium $(\mathrm{Cr})$, zinc $(\mathrm{Zn})$ and mercury $(\mathrm{Hg})$. For the determination of these metallic trace elements, the method X31-150 / Method according to NF EN 13650-NF EN ISO 11885 was used. For the undesirable elements (metals, plastics...) in the compost, the bleach is used to destroy non-synthetic organic matter [6].

\section{Results and Discussion}

\subsection{Agronomic Analyzes}

The different analyzes are made on samples of composts older than 6 months. Table 1 presents the results of the analysis of the agronomic parameters performed on our composts samples. These different results are expressed as a percentage.

Table 1. Analyzes of agronomic parameters.

\begin{tabular}{|c|c|c|c|c|c|c|c|}
\hline & MS & MO & N tk & $\mathbf{P}_{2} \mathbf{O}_{5}$ & $\mathbf{K}_{2} \mathbf{O}$ & $\mathrm{CaO}$ & ISMO \\
\hline Compost Lomé 1 & 91.3 & 20.4 & 0.51 & 0.73 & 1.02 & 5.1 & 915 \\
\hline Compost Lomé 2 & 92.3 & 15.6 & 0.45 & 0.55 & 0.8 & 4.5 & - \\
\hline Fines LOME 0-10 mm & 91.2 & 7.1 & 0.1 & 0.25 & 0.3 & 2.7 & - \\
\hline COMPOST OMR France & 68.1 & 31.5 & 1.1 & 0.4 & 0.5 & 5.3 & 61.5 \\
\hline COMPOST LOME REF & $55-70$ & $38-40$ & 1 & 0.4 & $?$ & 2 & - \\
\hline
\end{tabular}

The agronomic profile of the 2 samples of analyzed compost collected from Lomé 1 and Lomé 2 shows that there are few differences in quality between Lomé 1 compost and Lomé 2 compost and the Lomé 2 compost is even rather less rich in nutrient than Lomé 1 compost. This may probably be due to a significant presence of sand and wicks in this composted waste. This could also be explained by an advanced decomposition of these wastes which through leaches loses nutrients. Moreover, on the basis of these analyzes, the commercial differentiation made between the two types of compost is not justified or so, it is necessary to improve the traceability of the batches at the level of the storage of the compost and carry out a minimum of analyzes.

The long lasting storage of the compost on the platform (stored at least 3 months under the shed) induces a significant modification of the agronomic profile compared to the reference analysis: significant loss of nitrogen with a halving of its content and significant mineralization organic matter which is also practically halved. These potassium losses have no significant impact on the environment. From the standpoint these losses, which can represent up to $50 \%$ of the total quantities of potassium, are however to avoid [7].
Nitrogen losses are more likely to be gaseous (ammonia) and phosphorus losses are only possible in organic form, therefore by direct entrainment of compost particles into the medium. As first consequence, one of the two samples no longer complies with the U44051 standard for this parameter. Thus the nitrogen contents are low for the two composts (see Table 1) compared to those obtained by Kolédzi, (2011) [8] and Matejka et al (2001) [9].

The carrying out of the measurement of the SIOM parameter (Stability Index of the Organic Matter) made on the sample of Lomé 1 allows to appreciate the good quality of residual organic matter in composts since this index measures the proportion of organic matter that is present in the sample that is likely to produce a humus stable organic matter in the soil. But, according to Aziablé, 2017 [10], a high rate in organic matter allows the retention of metals. The higher this concentration, the more metals are trapped, decreasing their bioavailability for plants [10-12]. The risk is therefore low in terms of phytotoxicity after soil amendment $[10,11,13]$. Compost can therefore stabilize or immobilize metals in the solid phase. But the complexity of the biological, physical and chemical mechanisms governing the 
transfer of pollutants into the soil implies great caution [11]. Indeed, the comparison of this SIOM to that of a compost of French OMR, shows that the Togolese sample that can be described as on matured is likely to release $1 / 3$ more humus from the quantity total organic matter added to the soil as a reference OMR compost. $\mathrm{P}_{2} \mathrm{O}_{5}$ contents are higher than the indicated reference values for compost in Lomé and these relatively high values are very probably related to the degree of advanced mineralization of composts sampled, since phosphorus is not the opposite of nitrogen, rather a component volatile.

Potash contents $\left(\mathrm{K}_{2} \mathrm{O}\right)$, poorly documented in the few available analytic records are higher than Phosphorus contents. This result is logical for compost which originates predominantly from vegetable and improves the agronomic profile initially defined.

The phosphate, calcium, magnesium and potassium contents of our composts samples are higher than those obtained by Kolédzi, (2011) [7]; Matejka et al (2001) [8]. Fertilizer value of compost Lomé 1 (1 Ton for $90 \%$ of MS) NPK profile: $0.5 / 0.7 / 1$ : on the basis of a unit $\mathrm{N}, \mathrm{P}_{2} \mathrm{O}_{5}$ or $\mathrm{K}_{2} \mathrm{O}$ at 800 FCFA or $€ 1.2$, the fertilizer value of the compost is close to $18 \times 800=14,400$ FCFA that is $€ 22 /$ ton per returned parcel. For ADEME, the selling price of composts is on average between 15 and $19 € /$ ton of composts [7]. The average selling price is also correlated to the screening mesh.
The finer the compost, the higher the selling price is. It varies from $10 € / \mathrm{t}$ for unscreened compost to $34 € / \mathrm{t}$ for the thinnest screening $(0-10 \mathrm{~mm})$ [7].

The agronomic profile of the $0-10 \mathrm{~mm}$ fine sample indicates that the organic matter content is low to be used as an organic enrichment. Its integration in the compost is possible only if it is fresh and to be only carried out on order before shipment or delivery to the farmers and market gardeners.

On the basis of a $30 \% \mathrm{MO}$ crude compost, it is necessary to limit the incorporation of fines to $30 \%$ by gross mass of the initial mass of compost so as to maintain in the mixture an organic matter content of about $25 \%$ on crude.

Contents in nutrients and organic matter are good for use as top soil / compost in creating green spaces or special pleasure garden. This fine fraction is the same as the dump screen but has a quality guarantee via a minimum 1 month treatment / storage on the site before use in order to ensure its hygienic necessity.

\subsection{Environmental Analyzes}

The results of the environmental analyzes are shown in Table 2. The concentrations in metallic trace elements of the various determined elements $(\mathrm{Cd}, \mathrm{Cu}, \mathrm{Ni}, \mathrm{Pb}, \mathrm{Cr}, \mathrm{Zn}$ and $\mathrm{Hg}$ ) are expressed in ppm.

Table 2. Environmental Analyzes.

\begin{tabular}{|c|c|c|c|c|c|}
\hline & Compost LOME 1 & Compost LOME 2 & Fines LOME 0-10 mm & COMPOST OMR France & Norm U44051 France \\
\hline $\mathrm{Cd}$ & 0.6 & 0.45 & 0.2 & 0.5 & 3 \\
\hline $\mathrm{Cu}$ & 51 & 54.3 & 13 & 66 & 300 \\
\hline $\mathrm{Ni}$ & 11 & 13 & 5 & 13 & 60 \\
\hline $\mathrm{Pb}$ & 23 & 17 & 13 & 33 & 180 \\
\hline $\mathrm{Cr}$ & 18 & 19 & 16 & 31 & 120 \\
\hline $\mathrm{Zn}$ & 390 & 383 & 137 & 200 & 600 \\
\hline Glass + metal $>2 \mathrm{~mm}$ & 0.6 & - & - & 1.0 & 2 \\
\hline Plastic film $>5 \mathrm{~mm}$ & 0.0 & - & - & 0.0 & 0.3 \\
\hline Hard Plastic $>5 \mathrm{~mm}$ & 0.1 & - & - & 0.3 & 0.8 \\
\hline
\end{tabular}

These results show that the environmental profile of the two analyzed compost samples Lomé1 and Lomé 2 have contents in low metal trace elements, very below the limit values of the French standard U44051 and comparable to the French OMR reference compost. However, these compost do not present no potential pollution danger. It can be used in agriculture as soil enrichment without risk of contamination of the soil-plant system [1]. These results corroborate those of Aziable et al., 2017 [1].

The content of low physical impurities, also below the threshold values of the French standard U44051 and lower than those of a French OMR compost of reference, notably thanks to the virtual absence of glass in Lomé garbage (the $0.6 \%$ of the glass + metals parameter is related exclusively to the presence of metals in the compost) and the manual sorting of the plastic in the organic fraction put to compost. The environmental profile of the fine fraction $0-10 \mathrm{~mm}$ has very low trace metal content and much lower levels of composts Lomé 1 and Lomé 2 therefore usable for agriculture and / or use as top soil.

\section{Conclusion}

This study on the quality of compost and fine fraction produced and stored on the ENPRO composting platform in Lomé, Togo, shows that the long lasting storage of compost on the platform (at least 3 months under the shed) induces a notable modification of agronomic profile compared to the baseline analysis. The analysis of the environmental profile of the samples revealed low levels of trace metal elements, very below the limit values of the French standard U44051. These composts can be developed in agriculture without risk of contamination.

\section{Acknowledgements}

Laboratoire AUREA France via Suez Environnement. 


\section{References}

[1] E. Aziable, S. Tchegueni1, M. B. Bodjona1, A. K. Degbe, M. Zamama, M. Hafidi, M. EL Meray, K. A. Kili. Valorization of agro-industrial waste by bio-process aerobic, composting. Journal of Materials and Environmental Sciences (J. M. E. S), 2017, 8 (4), pp. 1277-1283.

[2] Bernal M. P., Alburquerque J. A. and Moral R., Bioresource Technology (2009), 100, 5444-5453.

[3] Moursalou KORIKO, Sanonka TCHEGUENI, Komi Edem KOLEDZI, Dihéénane D. BAFAI, Essey ZONVIDEY, Gado TCHANGBEDJI, Ani Koffi KILI, Mohamed HAFIDI, 2013. Extractions et caractérisations physico-chimiques des substances humiques naturelles des sols et du compost. Int. J. Biol. Chem. Sci. 7(3): 1405-1415.

[4] Sanonka TCHEGUENI, Koffi A. KILI, Magnoudéwa BODJONA, Moursalou KORIKO, Mohamed HAFIDI, Gnon BABA, Gado TCHANGBEDJI, 2012. Effets des composts à base de déchets d'agrumes et du tourteau de karité sur la disponibilité du phosphore du sol: une étude en conditions contrôlées. Int. J. Biol. Chem. Sci. 6(3): 1381-1389.

[5] El Fels L., Zamama M., El asli A., Hafidi M., 2014a: Assessment of biotransformation of organic matter during cocomposting of sewage sludgelignocelullosic waste by chemical, FTIR analyses, and phytotoxicity tests. International Biodeterioration and Biodegradation, 87, 128-137.

[6] AFNOR, 2004. Amendements organiques et supports de culture Méthode d'analyse des composants inertes dans un compost; Eds AFNOR; 14p.
[7] ADEME, 2015. Le compostage: Fiche technique.

[8] Koledzi K. Edem, 2011. Valorisation des déchets solides urbains dans les quartiers de Lomé (Togo): approche méthodologique pour une production durable de compost. Thèse de Doctorat unique de l'Université de Lomé en Cotutelle avec l'Université de Limoges; p. 178.

[9] Matejka, G., Barbier, J., De Las Heras, F., Klein, A., Paqueteau, F., Kebe, A., 2001. Composting of urban refuse in Labé (Guinea): process optimization and agricultural value; Cagliari (Sardinia) Eighth International Waste Management and Landfill Symposiuim (CISA: Environ. Sanitary Engineering Centre) 1 - 5 Oct. 2001.

[10] Aziablé E., 2017. Contribution à l'étude de la dépollution des sols charges en éléments traces métalliques $(\mathrm{Cd}, \mathrm{Cu}, \mathrm{Pb}, \mathrm{Zn})$ au voisinage de l'usine de traitement de phosphate de Kpémé (Togo). Thèse de Doctorat unique de l'Université de Lomé.

[11] Koledzi K. E., Baba Gnon, Segbeaya N., Tchangbedji G., Kili K., Tozo K., Gnandi K., Amouzouvi A. A., Feuillade G., Matejka G. Valorisation des déchets urbains en agriculture: étude d'impact écologique de Composts. Journal de la Société Ouest-Africaine de Chimie (J. Soc. Ouest-Afr. Chim), 2011, $032 ; 27-42$.

[12] Hargreaves, J. C., Adl, M. S., Warman, P. R., 2008. A review of the use of composted municipal solid waste in agriculture. Agriculture, Ecosystems and Environment 123 (2008) 1-14.

[13] Farrel, M., Jones, D. L., 2009. Critical evaluation of municipal solid waste composting and potential compost markets. Bioresource Technology 100 (2009) 4301- 4310. 